Published in final edited form as:

World J Surg. 2019 February ; 43(2): 385-394. doi:10.1007/s00268-018-4726-3.

\title{
Hypophosphatemia as a Predictor of Organ-Specific Complications Following Gastrointestinal Surgery: Analysis of 8,034 Patients
}

\author{
Eran Sadot, MD ${ }^{\# 1,2,3}$, Jian Zheng, $\mathbf{M D}^{\# 1}$, Rami Srouji, MD ${ }^{1}$, Vivian E. Strong, MD ${ }^{1}$, Mithat

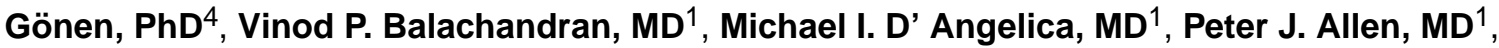 \\ Ronald P. DeMatteo, MD ${ }^{1}$, T. Peter Kingham, MD ${ }^{1}$, Yuman Fong, MD ${ }^{1,5}$, Martin R. Wesier, \\ $M^{1}$, and William R. Jarnagin, MD' \\ ${ }^{1}$ Department of Surgery, Memorial Sloan Kettering Cancer Center, New York, USA \\ ${ }^{2}$ Department of Surgery, Rabin Medical Center, Petah Tikva, Israel \\ ${ }^{3}$ Faculty of Medicine, Tel Aviv University, Tel Aviv, Israel \\ ${ }^{4}$ Department of Epidemiology and Biostatistics, Memorial Sloan Kettering Cancer Center, New \\ York, USA \\ ${ }^{5}$ Department of Surgery, City of Hope, CA, USA \\ \# These authors contributed equally to this work.
}

\section{Abstract}

Background: Organ-specific complications (OSC) remain serious potential sequela of gastrointestinal surgery. Hypophosphatemia correlates with poor outcomes and may be a harbinger of OSC after gastrointestinal surgery. Our goal was to describe and evaluate the relationship between postoperative phosphate levels and OSC.

Methods: Consecutive patients who underwent pancreatic, colorectal, or gastric resections were analyzed. OSC were defined as those resulting from failure of at least one anastomosis performed during the primary resection, manifesting as an anastomotic leak, fistula, and/or intra-abdominal abscess. Postoperative serum phosphate levels and other recognized OSC risk factors were compared among patients who did and did not develop OSC.

Results: A total of 8034 patients who underwent pancreatic ( $n=397)$, colorectal $(n=5808)$, or gastric $(n=1829)$ resections were included in the study. In each resection group, the majority of patients experienced hypophosphatemia post-resection with the nadir on postoperative day (POD) 2 , and the subgroups that developed OSC exhibited lower phosphate levels on POD3-7. On multivariate analysis, lower phosphate level on POD3 remained significantly associated with OSC following pancreatic resection (median [interquartile range] mmol/L, 0.65 [0.53-0.76] vs. 0.71 [0.61-0.84], $\mathrm{p}=0.045)$ and colorectal resection $(0.71$ [0.61-0.87] vs 0.77 [0.65-0.94], $\mathrm{p}=0.006)$,

Corresponding Author: William R. Jarnagin, MD, Department of Surgery, Memorial Sloan Kettering Cancer Center, 1275 York Avenue C-891, New York, NY 10065, Phone: 212-639-3624; Fax: 917-432-2387, jarnagiw@mskcc.org.

Disclosure: All authors report no conflict of interests regarding this study. 
and lower phosphate level on POD4 remained associated with OSC following gastric resection (0.87 [0.74-1.03] vs 0.96 [0.81-1.13], $\mathrm{p}=0.049)$.

Conclusion: This study identified a consistent trajectory of serum phosphate levels following 3 different gastrointestinal operations and association between early postoperative phosphate levels and OSC. Persistent lower phosphate levels should raise level of concern for evolving postoperative leak and may lead to earlier radiographic evaluation and treatment.

\section{Keywords}

Postoperative hypophosphatemia; leak; complication; pancreatectomy; gastrectomy; colorectal resection

\section{Introduction}

Hypophosphatemia is common in hospitalized patients, ranging from $0.2 \%-3 \%$ in all inpatients [1, 2], 30\% in intensive care unit patients [3, 4], 40\% in severe burn patients[5], $75 \%$ in severe trauma patients [6], and to $60 \%-85 \%$ in patients with infection and sepsis [7]. Additionally, hypophosphatemia has been reported after many surgical procedures, including hepatic resection [8, 9], thoracic surgery [10], cardiac and aortic surgery [11, 12]. As the majority of these studies did not adjust for confounding variables, the cause for hypophosphatemia is unclear. However, a consistent association remains between hypophosphatemia and poor clinical outcomes in various populations of hospitalized patients $[3,4,13-15]$.

Complications related to postoperative fistula, leak, and abscess are serious sequelae of gastrointestinal resections. Following pancreatic resection, the reported rates of these complications range between $10 \%$ and $30 \%$ [16, 17]. Pancreatic fistula is typically associated with significant perioperative morbidity, notably hemorrhage, sepsis, longer length of hospital stay, increased cost, and higher risk of perioperative mortality [16-19]. However, current risk assessment for leak-related complications is inadequate and infrequently affects management algorithms (i.e., drain placement and removal, prophylactic somatostatin analogues, prophylactic jejunostomy feeding tubes, early discharge, and discharge disposition). In a similar way, anastomotic leak is one of the most concerning complications in patients undergoing gastric [20] and colorectal resection [21]. Thus, there is a need to find markers of postoperative organ-specific complications (OSC) to facilitate early diagnosis and intervention in order to mitigate more serious sequelae.

The incidence and clinical correlates of hypophosphatemia after pancreatic, gastric, or colorectal resections have not been reported. We hypothesized that patients with OSC after gastrointestinal surgery will have significantly lower phosphate level as compared to patients without OSC. 


\section{Material and Methods}

\section{Study patients}

With the approval of Memorial Sloan Kettering Cancer Center (MSKCC) institutional review board, query of prospectively maintained, service-specific databases was performed. This search identified consecutive patients who underwent pancreatic $(1 / 2011-12 / 2012)$, gastric (1/2002 - 9/2015), or colorectal resection (1/2005 - 7/2015) for any diagnosis. Different time periods were included because of differences in the individual databases utilized. Only patients that underwent initial resections were included; patients underwent reoperations were excluded.

Patient demographic information and clinicopathological characteristics were obtained. Operative morbidity was recorded and graded in the MSKCC surgical events database [17, 22-26], This database uses a severity scale similar to others previously published and is consistent with the "Common Terminology Criteria for Adverse Events Version 4.0", endorsed by the National Institutes of Health and the National Cancer Institute (Supplementary Table 1 and 2) [25, 26], Postoperative leak-related complications (LRC) included pancreatic anastomotic leak, pancreatic fistula, or intra-abdominal abscess, as coded in MSKCC's Secondary Surgical Events program (Supplementary Table 1) [17, 25, 26]. Only clinically significant ( $\geq$ grade 2 ) LRC were recorded [17]. Postoperative intraabdominal infections (IAI) after colorectal surgery included intestinal or rectal leak, intestinal or rectal fistula, or intra-abdominal infection (Supplementary Table 2), whereas postoperative IAI after gastric resection included esophageal or intestinal leak, esophageal or intestinal fistula, or intra-abdominal infection (Supplementary Table 2) [20, 25, 26], OSC were defined as either LRC or IAI, and all complications were recorded within 90 days after operation.

Serum phosphate levels were collected from the preoperative clinic visit (within 2 weeks of operation) and then daily starting on the day of surgery and continuing through the date of discharge. Hypophosphatemia was defined as serum levels less than $2.4 \mathrm{mg} / \mathrm{dL}(<0.77$ $\mathrm{mmol} / \mathrm{L}$ ) as per MSKCC Department of Laboratory Medicine calibration and in consistent with prior literatures [13, 27], Phosphate serum levels are controlled mainly by the kidney and therefore we used the Chronic Kidney Disease Epidemiology Collaboration (CKD-EPI) formula to evaluate the kidney function by obtaining preoperative serum creatinine measurements and estimating the glomerular filtration rate (GFR) [28]. Patients with preoperative GFR $<60 \mathrm{ml} / \mathrm{min} / 1.73 \mathrm{~m}^{2}$ or age $<18$ years were excluded from the study $(\mathrm{n}=2362)$. Postoperative phosphate repletions over the first 3 postoperative days were also documented. In addition, serum white blood cell counts (WBC) on postoperative day 3 were obtained to control for an established marker of acute phase response.

\section{Statistical analysis}

Categorical variables were presented using frequency and percentage, and compared using chi-square test. Continuous variables were presented using the median with the first and third interquartile quartiles (IQR) for phosphate levels and the entire range for all other variables, and compared using Mann-Whitney test. A p-value $<0.05$ was considered 
significant. All variables with a P-value $<0.05$ on univariate analysis were entered into a multivariate logistic regression with backward Wald method with criteria for removal of $p$ value $\geq 0.05$. Separate multivariate models were created from phosphate level of each postoperative day with other OSC risk factors identified from univariate analysis for each of the 3 resected cohorts. Descriptive and comparative statistics were performed using SPSS version 22 (IBM Corp., Armonk, NY) and SAS 9.4 (SAS Institute, Cary, NC). Figures were plotted using GraphPad Prism (GraphPad Software, CA).

\section{Results}

\section{Patient characteristics}

During the study period, the pancreatic resection group included 397 patients, of whom 268 (68\%) underwent Whipple, and 77 (19\%) developed LRC $\geq$ grade 2 within 90 days postoperatively (Table 1 and Supplementary Table 1). The colorectal resection group included 5,808 patients, of whom 2,456 (42\%) underwent rectal resection, and 345 (6\%) developed IAI (Table 2 and Supplementary Table 2). The gastric resection group included 1,829 patients, of whom 864 (45\%) underwent esophagogastric resection, and $183(10 \%)$ patients developed IAI (Table 3 and Supplementary Table 2). In this consecutive series of resected patients in each group, the majority of the operations were for cancer. The median lengths of stays were 7 (IQR 6-9), 7 (IQR 5-9), and 9 (IQR 7-12) days for pancreatic, colorectal, and gastric resections, respectively.

\section{Phosphate levels}

Perioperative serum phosphate alterations for patients in each resection group (pancreatic, colorectal, and gastric) are depicted (Fig. 1A, 1B, and 1C, respectively). In all 3 groups, phosphate levels declined steadily postoperatively and noted the most significant hypophosphatemia as it reached nadir on POD2. The serum phosphorus levels on preoperative day, POD0, POD1, and POD2 were not statistically different between the patients who developed OSC and those who did not. However, the serum phosphate trajectories began to separate after POD2, with the patients who developed OSC showing a slower recovery of hypophosphatemia from POD3 through POD7.

\section{Organ-specific complications}

Since patients who developed OSC had significantly lower phosphate levels on POD3 to POD7 compared to those without OSC in univariate analysis, we further evaluated this relationship in the multivariate analysis with other pertinent OSC risk factors. In the pancreatic resection group, body mass index (BMI) $\geq 30 \mathrm{~kg} / \mathrm{m}^{2}$, soft pancreatic gland, abnormal WBC levels on POD3, and lower phosphate levels on POD3 were independently associated with LRC (Table 1). Lower phosphate levels on POD5 was also independently associated with LRC in a separate multivariate analysis (Supplementary Table 3). In the colorectal resection group, combined liver surgery, operative blood loss, abnormal WBC levels on POD3, and lower phosphate levels on POD3 remained significantly associated with IAI (Table 2). Lower phosphate levels on POD4 and 5 were also independently associated with LRC in separate multivariate analyses (Supplementary Table 4). Following gastric resection, only BMI $\geq 30 \mathrm{~kg} / \mathrm{m}^{2}$ and lower phosphate levels on POD4 were independently 
associated with IAI (Table 3). Lower phosphate levels on POD5 was also independently associated with IAI in a separate multivariate analysis (Supplementary Table 5).

\section{Phosphate supplementation}

Although phosphate supplementation was not standardized, phosphate supplementation on POD $0-3$ was not associated with a significantly higher rate of OSC compared to no supplementation (Table 1, 2, and 3). In addition, in patients with available data on daily phosphate supplementation (pancreatectomy group), those who received supplementation had a significant increase in phosphate level on the following day, and these levels were comparable to those given no supplementation. For example, patients who received phosphate supplementation on POD2 following partial pancreatectomy had increased phosphate level from POD2 to POD3 (median [interquartile range] mmol/L, $0.58[0.45-$ 0.65 ] to 0.68 [0.58-0.81], $\mathrm{p}<0.001)$. On the other hand, patients who did not receive phosphate supplementation on POD2 following partial pancreatectomy had no significant change in the phosphate level from POD2 to POD3 (0.81 [0.65-0.84] to 0.71 [0.58-0.84], $\mathrm{p}=0.094)$. Despite receiving phosphate supplementation on POD2 following partial pancreatectomy, these patients continued to experience lower phosphate levels on POD3, although the phosphate level was similar to that of patients who did not require supplementation (0.68 [0.58-0.81] vs. 0.71 [0.58-0.84], $\mathrm{p}=0.602)$.

\section{Discussion}

This study identified a consistent pattern of hypophosphatemia in a large number of patients following 3 different gastrointestinal operations. In addition, lower phosphate levels was associated with increased risk of OSC, independent of other established risk factors. The results suggest that early postoperative hypophosphatemia may foreshadow and allow for the early identification of patients at risk for OSC.

Hypophosphatemia is a common manifestation in patients who develop infection, burn and trauma, as well as after various surgical procedures [1-8, 10-12, 29-32]. In a consistent manner, the presence of hypophosphatemia was correlated with the poor outcomes, including respiratory failure, arrhythmia, heart failure, longer length of hospital stay, and increased postoperative complications [3, 4, 13-15]. The pathophysiologic mechanism by which hypophosphatemia is associated with or predicts an adverse outcome is unclear, as phosphate metabolism is multifactorial, and phosphate levels in surgical patients may be influenced by urinary loss during volume expansion, phosphate redistribution to the intracellular compartment during respiratory alkalosis or insulin/glucose infusion, and high levels of catecholamines [33]. Depending on the type of gastrointestinal surgery, patients in this study may not have any PO intake during early postoperative days. Majority of patients received normal saline or lactated ringer as resuscitative fluid for the first 24 hours, and then they were switched to dextrose $5 \%$ in $1 / 2$ normal saline $+20 \mathrm{mEq} / \mathrm{L}$ potassium chloride as maintenance fluid on POD 1 onward if they remained off diet.

Although dextrose may cause transcellular shift of phosphate, this shift would be transient. In a prospective cohort study, the authors found postoperative hypophosphatemia was related to hyperphosphaturia, as likely mediated by nicotinamide phosphoribosyltransferase 
(NAMPT), which acted as a phosphaturic factor as well as a metabolic enzyme that synthesizes nicotinamide adenine dinucleotides [34, 35], The role of NAMPT on OSC was not studied and it warrants additional investigation. Furthermore, whether hypophosphatemia is the symptom or cause of complication is also unclear. It may be possible that those with prolonged inflammation or infection from OSC lead to continued urinary wasting of phosphate and thus it causes both hypophosphatemia-related symptom and complications.

Several studies have evaluated hypophosphatemia in acute inflammatory or infectious state. Barak et al [7] studied patients with infection and sepsis and showed that early hypophosphatemia was associated with the severity of infection and with higher levels of inflammatory cytokines. Moreover, injection of IL-6, TNFa and IL-I $\beta$ in mice markedly decreased the serum phosphate levels. These findings were reinforced by Giovanni et al [13] who evaluated patients after hepatic resection and demonstrated an inverse correlation between hypophosphatemia and the APACHE II score. In addition, patients with severe hypophosphatemia were associated with an almost 4-fold risk of developing complications. The authors suggested that hypophosphatemia may predict complications by reflecting an early acute-phase response. It is noteworthy that recent studies have also described similar correlation between other inflammatory markers (e.g., C-reactive protein and procalcitonin) and OSC after pancreatic [36], colorectal [21,37], and gastric surgery [38].

Hypophosphatemia observed following gastrointestinal operations during the first 7 postoperative days is in line with previous reports of hypophosphatemia following hepatectomy $[13,39,40]$, The earliest difference in hypophosphatemia between the subgroups that did and did not develop OSC was noted on POD3. The importance of these time points were reported by Giaccaglia et al [21, 41] and Meisner et al [42]. On POD1 and 2 after intestinal surgery, they found no difference in inflammatory markers levels between the group who developed OSC and the group who did not developed OSC. However, on POD3, a significant difference was observed between the groups. They proposed that a physiological increase in the inflammatory markers takes place between POD1 and 2 after intestinal surgery, which may be explained in part by a transient bacterial translocation during the operation or by preparation of the intestinal anastomosis.

The main limitation of this study relates to its retrospective, nonrandomized design in which selection factors cannot be excluded. For example, daily serum phosphate measurements from day of resection until discharge were not complete for all patients, as shown in Tables 1 to 3. In an attempt to evaluate the significance of these missing phosphate data on some patients, we have also performed analysis excluding patients who had missing phosphate levels on both POD3 and POD4 (data not shown). In that univariate analysis, those with leak were associated with significantly lower level of phosphate on POD3 to 7 in all 3 groups except POD6 in the colorectal group. In the multivariate analysis in the same subset of patients, lower phosphate levels was significantly associated with OSC for POD3 and 5 in the pancreatic group, POD3 to 5 in colorectal group, but only POD5 in gastric group. A large, prospective study mandating evaluation of daily postoperative phosphate level would be needed to minimize these selection biases. Another limitation of the study is that phosphate repletion was not standardized, although patients who received phosphate 
supplementation did not result in a higher rate of OSC. In addition, although patients who received phosphate supplementation had increased phosphate level on the subsequent day, they continued to have lower phosphate levels and the level was similar to those who did not require supplementation. This implies that continued metabolic and inflammatory insult from OSC might lead to persistent lower phosphate levels despite of supplementation.

The strength of this study is the validation of the findings provided by the consistent pattern that was observed in 3 different organs (i.e., pancreas, stomach, and large bowel). In the current healthcare climate, where physicians face rising challenge of delivering high-quality care against the competing front of rising healthcare cost, this work has important potential implication, as it may facilitate implementation of enhanced recovery after surgery (ERAS) [43-45], The ERAS program may employ early postoperative hypophosphatemia to facilitate management decisions in patients who are potential candidates for early discharge. For example, patients without significant or sustained postoperative hypophosphatemia may be more reassured for earlier discharge. However, in patients with a persistent postoperative hypophosphatemia, they may not be the best candidates for early discharge. In these patients with hypophosphatemia along with other OSC risk factors, surgeons may develop a lower threshold for radiographic evaluation and drainage or may delay in removal of operative drain in order to monitor the output more closely. However, the impact of this study on ERAS patient is unclear. Since the median lengths of stay in this predominate cancer resection study were longer than one would expect from recent ERAS data, additional studies using ERAS patients is warranted although we may not be able to obtain postoperative phosphate data on some patients if they get discharged prior to POD7.

In summary, we identified a consistent trajectory of serum phosphate levels following 3 different gastrointestinal operations and an association between early postoperative lower phosphate levels and OSC. These findings may have clinical implications relevant to patients' monitoring, therapeutic interventions, and may help identify those who should not be targeted for early discharge. Future studies are warranted to determine the predictive performance of phosphate levels for OSC and in conjunction with other clinical variables.

\title{
Supplementary Material
}

Refer to Web version on PubMed Central for supplementary material.

\section{Acknowledgement}

None

Financial support: Funded in part by the NIH/NCI Cancer Center Support Grant P30 CA008748.

\author{
Abbreviations: \\ OSC organ-specific complications \\ POD postoperative day \\ LRC leak-related complications
}




$\begin{array}{ll}\text { IAI } & \text { intra-abdominal infections } \\ \text { CKD-EPI } & \text { Chronic Kidney Disease Epidemiology Collaboration } \\ \text { GFR } & \text { glomerular filtration rate } \\ \text { WBC } & \text { white blood cell counts } \\ \text { IQR } & \text { interquartile range } \\ \text { BMI } & \text { body mass index } \\ \text { PDAC } & \text { pancreatic ductal adenocarcinoma } \\ \text { IPMN } & \text { intraductal papillary mucinous neoplasm } \\ \text { PNET } & \text { pancreatic neuroendocrine tumor } \\ \text { NAMPT } & \text { nicotinamide phosphoribosyltransferase } \\ \text { ERAS } & \text { enhanced recovery after surgery }\end{array}$

\section{References}

1. Larsson L, Rebel K, Sorbo B (1983) Severe hypophosphatemia--a hospital survey. Acta medica Scandinavica 214:221-223 [PubMed: 6660029]

2. King AL, Sica DA, Miller G, et al. (1987) Severe hypophosphatemia in a general hospital population. Southern medical journal 80:831-835 [PubMed: 3603104]

3. Zazzo JF, Troche G, Ruel P, et al. (1995) High incidence of hypophosphatemia in surgical intensive care patients: efficacy of phosphorus therapy on myocardial function. Intensive care medicine 21:826-831 [PubMed: 8557871]

4. Marik PE, Bedigian MK (1996) Refeeding hypophosphatemia in critically ill patients in an intensive care unit. A prospective study. Arch Surg 131:1043-1047 [PubMed: 8857900]

5. Berger MM, Rothen C, Cavadini C, et al. (1997) Exudative mineral losses after serious burns: a clue to the alterations of magnesium and phosphate metabolism. The American journal of clinical nutrition 65:1473-1481 [PubMed: 9129479]

6. Daily WH, Tonnesen AS, Allen SJ (1990) Hypophosphatemia--incidence, etiology, and prevention in the trauma patient. Critical care medicine 18:1210-1214 [PubMed: 2225887]

7. Barak V, Schwartz A, Kalickman I, et al. (1998) Prevalence of hypophosphatemia in sepsis and infection: the role of cytokines. Am J Med 104:40-47 [PubMed: 9528718]

8. Pomposelli JJ, Pomfret EA, Burns DL, et al. (2001) Life-threatening hypophosphatemia after right hepatic lobectomy for live donor adult liver transplantation. Liver transplantation: official publication of the American Association for the Study of Liver Diseases and the International Liver Transplantation Society 7:637-642

9. Herbert GS, Prussing KB, Simpson AL, et al. (2015) Early trends in serum phosphate and creatinine levels are associated with mortality following major hepatectomy. HPB: the official journal of the International Hepato Pancreato Biliary Association 17:1058-1065 [PubMed: 26385577]

10. Goldstein J, Vincent JL, Leclerc JL, et al. (1985) Hypophosphatemia after cardiothoracic surgery. Intensive care medicine 11:144-148 [PubMed: 3998274]

11. Cohen J, Kogan A, Sahar G, et al. (2004) Hypophosphatemia following open heart surgery: incidence and consequences. Eur J Cardiothorac Surg 26:306-310 [PubMed: 15296888]

12. Andersen PT, Nielsen LK, Moller-Petersen J, et al. (1987) Severe hypophosphatemia following elective abdominal aortic bypass grafting. Acta Chir Scand 153:641-646 [PubMed: 3434107] 
13. Giovannini I, Chiarla C, Nuzzo G (2002) Pathophysiologic and clinical correlates of hypophosphatemia and the relationship with sepsis and outcome in postoperative patients after hepatectomy. Shock 18:111-115 [PubMed: 12166771]

14. Ognibene A, Ciniglio R, Greifenstein A, et al. (1994) Ventricular tachycardia in acute myocardial infarction: the role of hypophosphatemia. Southern medical journal 87:65-69 [PubMed: 7506845]

15. Kagansky N, Levy S, Koren-Morag N, et al. (2005) Hypophosphataemia in old patients is associated with the refeeding syndrome and reduced survival. Journal of internal medicine 257:461-468 [PubMed: 15836663]

16. Butturini G, Daskalaki D, Molinari E, et al. (2008) Pancreatic fistula: definition and current problems. Journal of hepato-biliary-pancreatic surgery 15:247-251 [PubMed: 18535760]

17. Vin Y, Sima CS, Getrajdman GI, et al. (2008) Management and outcomes of postpancreatectomy fistula, leak, and abscess: results of 908 patients resected at a single institution between 2000 and 2005. J Am Coll Surg 207:490-498 [PubMed: 18926450]

18. El Nakeeb A, Salah T, Sultan A, et al. (2013) Pancreatic Anastomotic Leakage after Pancreaticoduodenectomy. Risk factors, Clinical predictors, and Management (Single Center Experience). World Journal of Surgery 37:1405-1418 [PubMed: 23494109]

19. Machado NO (2012) Pancreatic fistula after pancreatectomy: definitions, risk factors, preventive measures, and management-review. International journal of surgical oncology 2012:602478 [PubMed: 22611494]

20. Selby LV, Vertosick EA, Sjoberg DD, et al. (2015) Morbidity after Total Gastrectomy: Analysis of 238 Patients. Journal of the American College of Surgeons 220:863-871 e862 [PubMed: 25842172]

21. Giaccaglia V, Salvi PF, Antonelli MS, et al. (2015) Procalcitonin Reveals Early Dehiscence in Colorectal Surgery: The PREDICS Study. Ann Surg

22. Grobmyer SR, Pieracci FM, Allen PJ, et al. (2007) Defining morbidity after pancreaticoduodenectomy: use of a prospective complication grading system. J Am Coll Surg 204:356-364 [PubMed: 17324768]

23. Park J, Pillarisetty VG, Brennan MF, et al. (2010) Electronic synoptic operative reporting: assessing the reliability and completeness of synoptic reports for pancreatic resection. J Am Coll Surg 211:308-315 [PubMed: 20800186]

24. Correa-Gallego C, Brennan MF, D’Angelica M, et al. (2013) Operative drainage following pancreatic resection: analysis of 1122 patients resected over 5 years at a single institution. Ann Surg 258:1051-1058 [PubMed: 23360918]

25. Strong VE, Selby LV, Sovel M, et al. (2015) Development and assessment of Memorial Sloan Kettering Cancer Center's Surgical Secondary Events grading system. Annals of surgical oncology 22:1061-1067 [PubMed: 25319579]

26. Selby LV, Sjoberg DD, Cassella D, et al. (2015) Comparing surgical infections in National Surgical Quality Improvement Project and an Institutional Database. The Journal of surgical research 196:416-420 [PubMed: 25840487]

27. George R, Shiu MH (1992) Hypophosphatemia after major hepatic resection. Surgery 111:281-286 [PubMed: 1311873]

28. Levey AS, Stevens LA, Schmid CH, et al. (2009) A new equation to estimate glomerular filtration rate. Annals of internal medicine 150:604-612 [PubMed: 19414839]

29. Rasmussen A, Kimose HH, Hessov I (1988) Severity of postoperative hypophosphatemia in relation to glucose administration and renal handling of phosphate. Acta Chir Scand 154:617-621 [PubMed: 3232477]

30. Rasmussen A (1985) Hypophosphatemia during postoperative glucose infusion. Acta Chir Scand 151:497-500 [PubMed: 4090879]

31. Huber L, Naik M, Budde K (2013) Frequency and long-term outcomes of post-transplant hypophosphatemia after kidney transplantation. Transplant international: official journal of the European Society for Organ Transplantation 26:e94-96 [PubMed: 23937423]

32. Hessov I, Jensen NG, Rasmussen A (1980) Prevention of hypophosphatemia during postoperative routine glucose administration. Acta Chir Scand 146:109-114 [PubMed: 6774541] 
33. Ronco C, Bellomo R, Kellum J, Critical Care Nephrology (2nd Edition) (2008) Elsevier Health Sciences, Philadelphia, PA, USA

34. Zheng J, Glezerman IG, Sadot E, et al. (2017) Hypophosphatemia after Hepatectomy or Pancreatectomy: Role of the Nicotinamide Phosphoribosyltransferase. Journal of the American College of Surgeons

35. Nomura K, Tatsumi S, Miyagawa A, et al. (2014) Hepatectomy-related hypophosphatemia: a novel phosphaturic factor in the liver-kidney axis. J Am Soc Nephrol 25:761-772 [PubMed: 24262791]

36. Palani Velu LK, McKay CJ, Carter CR, et al. (2016) Serum amylase and C-reactive protein in risk stratification of pancreas-specific complications after pancreaticoduodenectomy. Br J Surg 103:553-563 [PubMed: 26898605]

37. Facy O, Paquette B, Orry D, et al. (2016) Diagnostic Accuracy of Inflammatory Markers As Early Predictors of Infection After Elective Colorectal Surgery: Results From the IMACORS Study. Ann Surg 263:961-966 [PubMed: 26135691]

38. Munoz JL, Ruiz-Tovar J, Miranda E, et al. (2016) C-Reactive Protein and Procalcitonin as Early Markers of Septic Complications after Laparoscopic Sleeve Gastrectomy in Morbidly Obese Patients Within an Enhanced Recovery After Surgery Program. J Am Coll Surg

39. Salem RR, Tray K (2005) Hepatic Resection-Related Hypophosphatemia Is of Renal Origin as Manifested by Isolated Hyperphosphaturia. Annals of surgery 241:343-348 [PubMed: 15650646]

40. Nafidi O, Lapointe RW, Lepage R, et al. (2009) Mechanisms of renal phosphate loss in liver resection-associated hypophosphatemia. Annals of surgery 249:824-827 [PubMed: 19387319]

41. Giaccaglia V, Salvi PF, Cunsolo GV, et al. (2014) Procalcitonin, as an early biomarker of colorectal anastomotic leak, facilitates enhanced recovery after surgery. Journal of critical care 29:528-532 [PubMed: 24798346]

42. Meisner M, Tschaikowsky K, Hutzler A, et al. (1998) Postoperative plasma concentrations of procalcitonin after different types of surgery. Intensive care medicine 24:680-684 [PubMed: 9722037]

43. Coolsen MM, van Dam RM, Chigharoe A, et al. (2014) Improving outcome after pancreaticoduodenectomy: experiences with implementing an enhanced recovery after surgery (ERAS) program. Digestive surgery 31:177-184 [PubMed: 25097014]

44. Liu VX, Rosas E, Hwang J, et al. (2017) Enhanced Recovery After Surgery Program Implementation in 2 Surgical Populations in an Integrated Health Care Delivery System. JAMA surgery 152:e171032 [PubMed: 28492816]

45. Ljungqvist O, Scott M, Fearon KC (2017) Enhanced Recovery After Surgery: A Review. JAMA surgery 152:292-298 [PubMed: 28097305] 
Pancreatic Resection

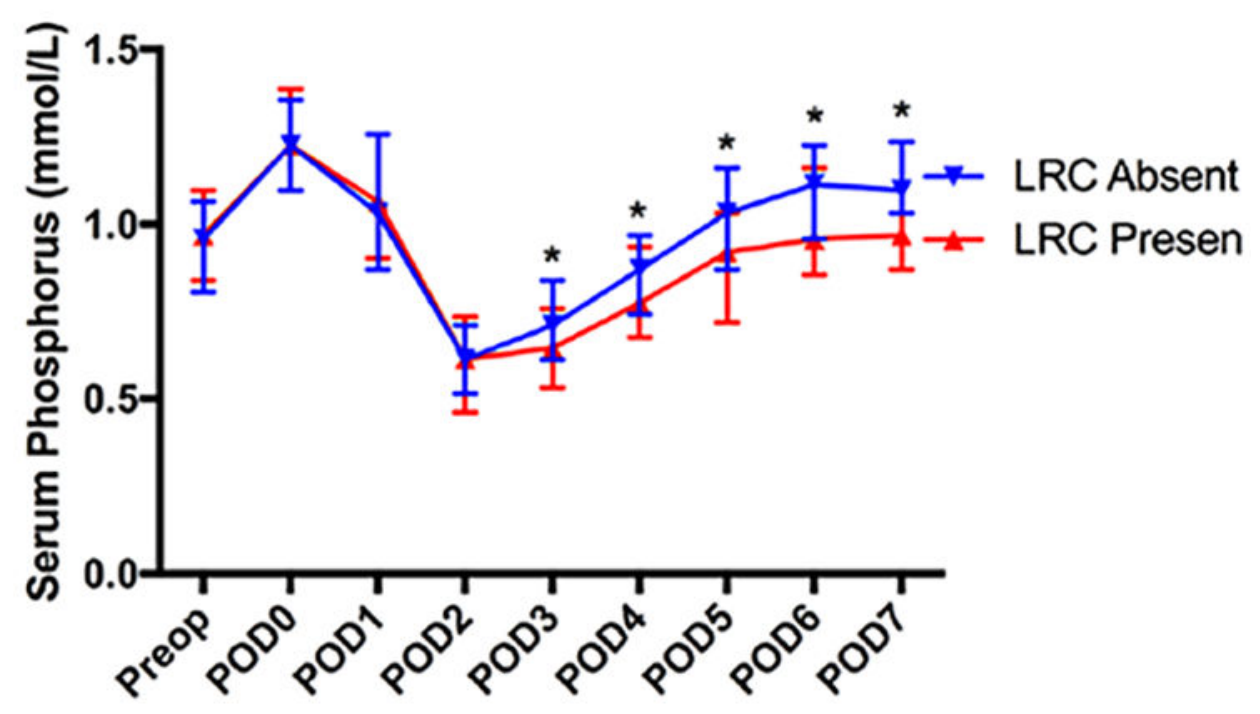

Colorectal Resection

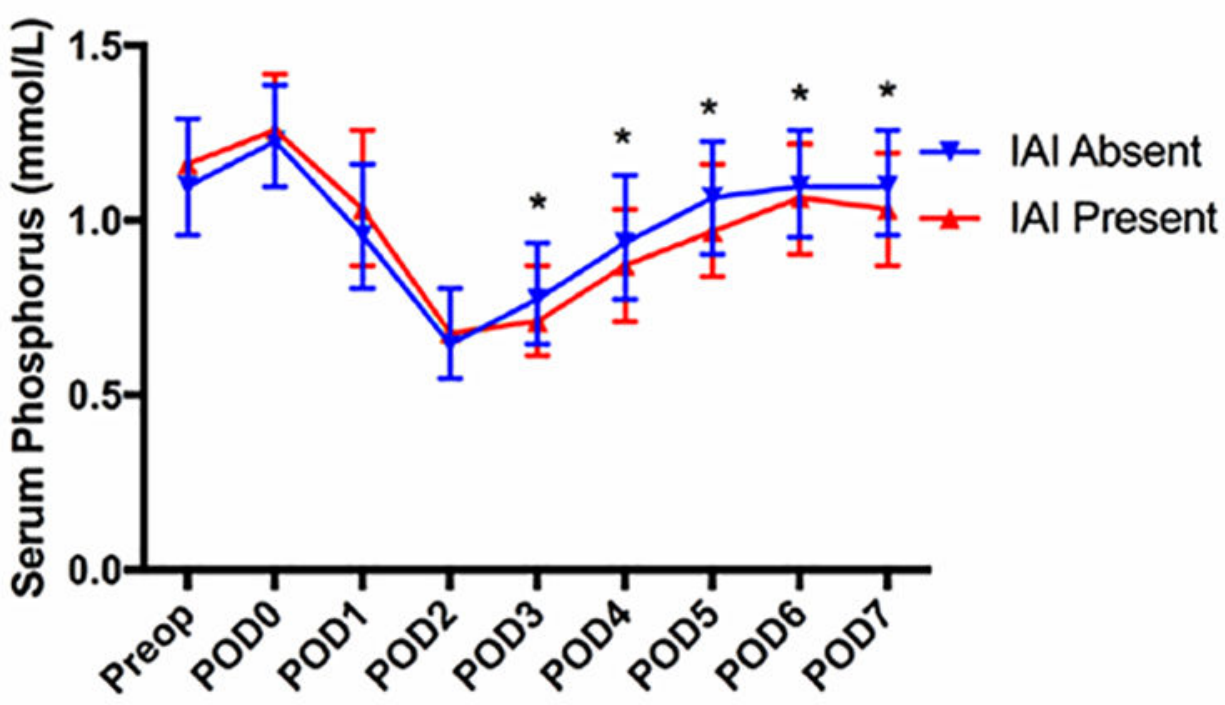




\section{Gastric Resection}

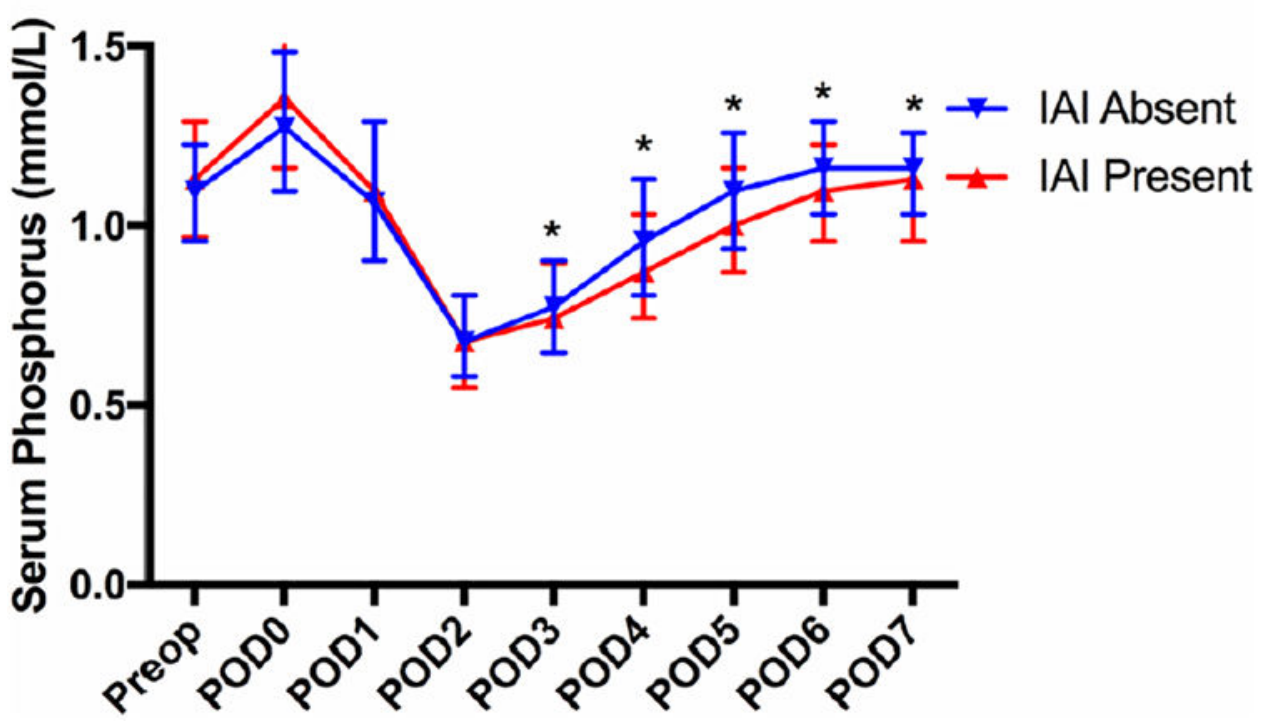

Fig. 1.

Perioperative serum phosphate alteration following pancreatic resection $(n=397)$ (Fig. 1A), colorectal resection $(n=5808)$ (Fig. 1B), and gastric resection $(n=1829)$ (Fig. 1C). Lines represent median \pm first and third interquartile range. 
Table 1.

Pancreatic resection cohort $(\mathrm{n}=397)$ characteristics stratified by leak-related complications.

\begin{tabular}{|c|c|c|c|c|c|}
\hline & \multirow{2}{*}{$\begin{array}{l}\text { All patients }(\mathbf{n} \\
\quad=397)\end{array}$} & \multicolumn{2}{|c|}{ Leak-related complications } & \multirow[t]{2}{*}{ P-value (univariate analysis) } & \multirow{2}{*}{$\begin{array}{l}\text { P-value OR (95\% } \\
\text { Cl) (multivariate } \\
\text { analysis with } \\
\text { POD3 phosphate) }\end{array}$} \\
\hline & & No $(n=320)$ & Yes $(n=77)$ & & \\
\hline Age & $64(56-73)$ & $65(57-73)$ & $63(55-71)$ & 0.282 & NA \\
\hline Male & $211(53 \%)$ & $164(51 \%)$ & $47(61 \%)$ & 0.129 & NA \\
\hline BMI $\geq 30 \mathrm{~kg} / \mathrm{m}^{2}$ & $125(32 \%)$ & $90(28 \%)$ & $35(46 \%)$ & 0.004 & $\begin{array}{c}0.014 \\
2.159(1.171-3.981)\end{array}$ \\
\hline Diabetes mellitus & $87(22 \%)$ & $66(21 \%)$ & $21(27 \%)$ & 0.221 & NA \\
\hline Albumin $<4.0 \mathrm{~g} / \mathrm{dL}$ & $273(69 \%)$ & $222(70 \%)$ & $51(66 \%)$ & 0.585 & NA \\
\hline Preoperative chemotherapy & $42(11 \%)$ & $33(10 \%)$ & $9(12 \%)$ & 0.684 & NA \\
\hline Preoperative stent & $122(32 \%)$ & $99(32 \%)$ & $23(31 \%)$ & 0.890 & NA \\
\hline Laparoscopic surgery & $33(8 \%)$ & $29(9 \%)$ & $4(5 \%)$ & 0.360 & NA \\
\hline Whipple & $268(68 \%)$ & $210(66 \%)$ & $58(75 \%)$ & 0.106 & NA \\
\hline $\begin{array}{l}\text { Diagnosis } \\
\text { PDAC } \\
\text { IPMN } \\
\text { PNET } \\
\text { Serous cystadenoma } \\
\text { Retention cyst } \\
\text { Others }\end{array}$ & $\begin{array}{c}253(64 \%) \\
56(14 \%) \\
38(10 \%) \\
16(4 \%) \\
5(1 \%) \\
29(7 \%)\end{array}$ & $\begin{array}{c}209(65 \%) \\
48(15 \%) \\
29(9 \%) \\
10(3 \%) \\
3(1 \%) \\
21(7 \%)\end{array}$ & $\begin{array}{l}44(57 \%) \\
8(10 \%) \\
9(12 \%) \\
6(8 \%) \\
2(3 \%) \\
8(10 \%)\end{array}$ & 0.157 & NA \\
\hline Duct diameter $<3 \mathrm{~mm}$ & $159(43 \%)$ & $118(40 \%)$ & $41(56 \%)$ & 0.012 & $\begin{array}{c}0.763 \\
1.105(0.578-2.111)\end{array}$ \\
\hline Soft gland & $213(58 \%)$ & $159(54 \%)$ & $54(74 \%)$ & 0.002 & $\begin{array}{c}0.007 \\
2.528(1.292-4.946)\end{array}$ \\
\hline Intraoperative drain & $136(37 \%)$ & $104(36 \%)$ & $32(44 \%)$ & 0.223 & NA \\
\hline Operative time, mins & $222(167-292)$ & $218(163-289)$ & $229(179-297)$ & 0.256 & NA \\
\hline Operative blood loss, $\mathrm{mL}$ & $300(200-650)$ & $300(200-600)$ & $450(250-700)$ & 0.007 & $\begin{array}{c}0.057 \\
1.001(1.000-1.001)\end{array}$ \\
\hline $\begin{array}{l}\text { Abnormal WBC on POD3 } \\
\text { (outside of } 4-11 \mathrm{~K} / \mathrm{uL} \text { ) }\end{array}$ & $294(75 \%)$ & $233(74 \%)$ & $61(79 \%)$ & 0.381 & NA \\
\hline $\begin{array}{l}\text { Any phosphate supplement } \\
\text { PODO-3 }\end{array}$ & $265(67 \%)$ & $210(66 \%)$ & $55(71 \%)$ & 0.349 & NA \\
\hline $\begin{array}{l}\text { POD2 phosphate, } \mathrm{mmol} / \mathrm{L} \\
\text { Available }^{\#}\end{array}$ & $\begin{array}{c}0.61(0.52-0.71) \\
277(70 \%)\end{array}$ & $\begin{array}{c}0.61(0.52-0.71) \\
221(69 \%)\end{array}$ & $\begin{array}{c}0.61(0.46-0.73) \\
56(73 \%)\end{array}$ & 0.885 & $\begin{array}{c}0.616 \\
1.568(0.2719 .075)\end{array}$ \\
\hline $\begin{array}{l}\text { POD3 phosphate, } \mathrm{mmol} / \mathrm{L} \\
\text { Available }^{\#}\end{array}$ & $\begin{array}{l}0.71(0.58-0.84) \\
291(73 \%)\end{array}$ & $\begin{array}{l}0.71(0.61-0.84) \\
230(72 \%)\end{array}$ & $\begin{array}{l}0.65(0.53-0.76) \\
61(79 \%)\end{array}$ & 0.011 & $\begin{array}{c}0.045 \\
0.168(0.0290 .963)\end{array}$ \\
\hline $\begin{array}{l}\text { POD4 phosphate, } \mathrm{mmol} / \mathrm{L} \\
\text { Available }\end{array}$ & $\begin{array}{c}0.87(0.71-0.97) \\
257(65 \%)\end{array}$ & $\begin{array}{c}0.87(0.74-0.97) \\
203(71 \%)\end{array}$ & $\begin{array}{c}0.77(0.68-0.94) \\
54(70 \%)\end{array}$ & 0.011 & $\begin{array}{c}0.256 \\
0.381(0.0722 .012)\end{array}$ \\
\hline $\begin{array}{l}\text { POD5 phosphate, mmol/L } \\
\text { Available }\end{array}$ & $\begin{array}{c}0.97(0.87-1.13) \\
227(57 \%)\end{array}$ & $\begin{array}{c}1.03(0.87-1.16) \\
179(64 \%)\end{array}$ & $\begin{array}{c}0.92(0.72-1.03) \\
48(62 \%)\end{array}$ & $<0.001$ & $\begin{array}{c}0.001 \\
0.052(0.0090 .297)\end{array}$ \\
\hline
\end{tabular}

Separate multivariate analysis of phosphate levels on each day below was performed with all significant factors from univariate analysis above. Multivariate analysis with POD3 phosphate level is shown above, and the analyses with the other PODs are shown in the Supplementary Table 3.

Abbreviations: BMI, body mass index; PDAC, pancreatic ductal adenocarcinoma; IPMN, intraductal papillary mucinous neoplasm; PNET, pancreatic neuroendocrine tumor; WBC, white blood cell count; NA, not analyzed. Categorical variables are expressed as frequency (\%). Phosphate levels and all other continuous variables are expressed as median ( $1^{\mathrm{st}}-3^{\text {rd }}$ interquartile range). Number (\%) of patients with available phosphate level are as denoted (\#). 
Table 2.

Colorectal resection cohort $(\mathrm{n}=5808)$ characteristics stratified by intra-abdominal infection.

\begin{tabular}{|c|c|c|c|c|c|}
\hline & \multirow[t]{2}{*}{ All patients $(\mathrm{n}=5808)$} & \multicolumn{2}{|c|}{ Intra-abdominal infection } & \multirow[t]{2}{*}{ P-value (univariate analysis) } & \multirow{2}{*}{$\begin{array}{l}\text { P-value OR (95\% } \\
\text { Cl) (multivariate } \\
\text { analysis with } \\
\text { POD3 phosphate) }\end{array}$} \\
\hline & & No $(n=5463)$ & Yes $(n=345)$ & & \\
\hline Age & $58(49-67)$ & $58(49-67)$ & $56(48-66)$ & 0.323 & NA \\
\hline Male & $2820(49 \%)$ & $2665(49 \%)$ & $155(45 \%)$ & 0.166 & NA \\
\hline BMI $\geq 30 \mathrm{~kg} / \mathrm{m}^{2}$ & $1241(29 \%)$ & $1179(29 \%)$ & $62(23 \%)$ & 0.023 & $\begin{array}{c}0.092 \\
0.719(0.490-1.056)\end{array}$ \\
\hline Diabetes mellitus & $677(12 \%)$ & $632(12 \%)$ & $45(13 \%)$ & 0.388 & NA \\
\hline Chronic steroid use & $152(3 \%)$ & $140(3 \%)$ & $12(4 \%)$ & 0.295 & NA \\
\hline Albumin $<4.0 \mathrm{~g} / \mathrm{dL}$ & $1240(22 \%)$ & $1134(21 \%)$ & $106(31 \%)$ & 0.000 & $\begin{array}{c}0.169 \\
1.284(0.899-1.833)\end{array}$ \\
\hline $\begin{array}{l}\text { Diagnosis } \\
\text { Colon CA } \\
\text { Rectal CA } \\
\text { Retroperitoneal CA } \\
\text { Other CA } \\
\text { Benign tumors }\end{array}$ & $\begin{array}{c}2863(48 \%) \\
1660(28 \%) \\
122(2 \%) \\
893(15 \%) \\
425(7 \%)\end{array}$ & $\begin{array}{c}2719(48 \%) \\
1571(28 \%) \\
107(2 \%) \\
810(14 \%) \\
405(7 \%)\end{array}$ & $\begin{array}{c}144(41 \%) \\
89(25 \%) \\
15(4 \%) \\
83(24 \%) \\
20(6 \%)\end{array}$ & 0.000 & $\begin{array}{c}0.227 \\
1.085(0.951-1.237)\end{array}$ \\
\hline Rectal resections & $2456(42 \%)$ & $2299(42 \%)$ & $157(46 \%)$ & 0.217 & NA \\
\hline Combined liver surgery & $885(15 \%)$ & $792(15 \%)$ & $93(27 \%)$ & 0.000 & $\begin{array}{c}0.034 \\
1.468(1.029-2.095)\end{array}$ \\
\hline Combined gynecological surgery & $1186(20 \%)$ & $1104(20 \%)$ & $82(24 \%)$ & 0.113 & NA \\
\hline Combined urology surgery & $814(14 \%)$ & $747(14 \%)$ & $67(19 \%)$ & 0.004 & $\begin{array}{c}0.965 \\
1.010(0.657-1.551)\end{array}$ \\
\hline Combined vascular surgery & $39(1 \%)$ & $35(1 \%)$ & $4(1 \%)$ & 0.290 & NA \\
\hline Combined orthopedic surgery & $63(1 \%)$ & $60(1 \%)$ & $3(1 \%)$ & 1.000 & NA \\
\hline Combined esophagogastric surgery & $53(1 \%)$ & $48(1 \%)$ & $5(1 \%)$ & 0.243 & NA \\
\hline Diverting ileostomy & $715(12 \%)$ & $672(12 \%)$ & $43(13 \%)$ & 0.933 & NA \\
\hline Diverting colostomy & $126(2 \%)$ & $121(2 \%)$ & $5(1 \%)$ & 0.446 & NA \\
\hline Operative time, mins & $238(168-337)$ & $234(166-333)$ & $292(207-398)$ & $<0.001$ & $\begin{array}{c}0.856 \\
1.000(0.999-1.001)\end{array}$ \\
\hline Operative blood loss, $\mathrm{mL}$ & $50(50-200)$ & $50(50-200)$ & $113(50-300)$ & $<0.001$ & $\begin{array}{c}0.002 \\
1.001(1.000-1.002)\end{array}$ \\
\hline $\begin{array}{l}\text { Abnormal WBC on POD3 (outside } \\
\text { of } 4-11 \mathrm{~K} / \mathrm{uL} \text { ) }\end{array}$ & $116(24 \%)$ & $999(23 \%)$ & $117(38 \%)$ & 0.000 & $\begin{array}{c}0.000 \\
1.897(1.348-2.670)\end{array}$ \\
\hline $\begin{array}{l}\text { Any phosphate supplement } \\
\text { POD\#0-3 }\end{array}$ & $1615(28 \%)$ & $1483(27 \%)$ & $132(38 \%)$ & 0.000 & $\begin{array}{c}0.754 \\
0.944(0.659-1.353)\end{array}$ \\
\hline $\begin{array}{l}\text { POD2 phosphate, } \mathrm{mmol} / \mathrm{L} \\
\text { Available }\end{array}$ & $\begin{array}{c}0.65(0.55-0.81) \\
3366(58 \%)\end{array}$ & $\begin{array}{l}0.65(0.55-0.81) \\
3129(57 \%)\end{array}$ & $\begin{array}{c}0.67(0.55-0.81) \\
237(69 \%)\end{array}$ & 0.516 & $\begin{array}{c}0.194 \\
0.543(0.216-1.365)\end{array}$ \\
\hline $\begin{array}{l}\text { POD3 phosphate, mmol/L } \\
\text { Available }\end{array}$ & $\begin{array}{l}0.77(0.65-0.94) \\
\quad 3144(54 \%)\end{array}$ & $\begin{array}{l}0.77(0.65-0.94) \\
2905(53 \%)\end{array}$ & $\begin{array}{l}0.71(0.61-0.87) \\
239(69 \%)\end{array}$ & $<0.001$ & $\begin{array}{c}0.006 \\
0.308(0.133-0.713)\end{array}$ \\
\hline $\begin{array}{l}\text { POD4 phosphate, mmol/L } \\
\text { Available }\end{array}$ & $\begin{array}{l}0.94(0.78-1.13) \\
2681(46 \%)\end{array}$ & $\begin{array}{l}0.94(0.77-1.13) \\
2466(45 \%)\end{array}$ & $\begin{array}{l}0.87(0.71-1.03) \\
215(62 \%)\end{array}$ & $<0.001$ & $\begin{array}{c}0.000 \\
0.258(0.121-0.549)\end{array}$ \\
\hline $\begin{array}{l}\text { POD5 phosphate, } \mathrm{mmol} / \mathrm{L} \\
\text { Available }\end{array}$ & $\begin{array}{l}1.03(0.87-1.23) \\
2262(39 \%)\end{array}$ & $\begin{array}{c}1.06(0.90-1.23) \\
2064(38 \%)\end{array}$ & $\begin{array}{l}0.97(0.84-1.16) \\
198(57 \%)\end{array}$ & $<0.001$ & $\begin{array}{c}0.016 \\
0.367(0.162-0.828)\end{array}$ \\
\hline
\end{tabular}

Separate multivariate analysis of phosphate levels at each day below was performed with all significant factors from univariate analysis above.

Multivariate analysis with POD3 phosphate level is shown above, and the analyses with the other PODs are shown in the Supplementary Table 4. 
Abbreviations: BMI, body mass index; CA, cancer; WBC, white blood cell count; NA, not analyzed. Categorical variables are expressed as frequency (\%). Phosphate levels and all other continuous variables are expressed as median ( $1^{\text {st }}-3^{\text {rd }}$ interquartile range). Number (\%) of patients with available phosphate level are as denoted (\#). 
Table 3.

Gastric resection cohort $(\mathrm{n}=1829)$ characteristics stratified by intra-abdominal infection.

\begin{tabular}{|c|c|c|c|c|c|}
\hline & \multirow[t]{2}{*}{ All patients $(n=1829)$} & \multicolumn{2}{|c|}{ Intra-abdominal infection } & \multirow[t]{2}{*}{ P-value (univariate analysis) } & \multirow{2}{*}{$\begin{array}{l}\text { P-value OR (95\% } \\
\text { Cl) (multivariate } \\
\text { analysis with } \\
\text { POD4 phosphate) }\end{array}$} \\
\hline & & No $(n=1646)$ & Yes $(n=183)$ & & \\
\hline Age & $61(53-69)$ & $62(53-70)$ & $60(53-68)$ & 0.352 & NA \\
\hline Male & $1829(100 \%)$ & $1131(69 \%)$ & $141(77 \%)$ & 0.022 & $\begin{array}{c}0.886 \\
1.042(0.594-1.829)\end{array}$ \\
\hline BMI $\geq 30 \mathrm{~kg} / \mathrm{m}^{2}$ & $348(29 \%)$ & $294(27 \%)$ & $54(44 \%)$ & 0.000 & $\begin{array}{c}0.007 \\
1.887(1.193-2.986)\end{array}$ \\
\hline Diabetes mellitus & $253(14 \%)$ & $222(14 \%)$ & $31(17 \%)$ & 0.214 & NA \\
\hline Chronic steroid use & $59(3 \%)$ & $54(3 \%)$ & $5(3 \%)$ & 0.828 & NA \\
\hline Albumin $<4.0 \mathrm{~g} / \mathrm{dL}$ & $468(26 \%)$ & $425(26 \%)$ & $43(24 \%)$ & 0.531 & NA \\
\hline Esophagogastrectomy & $864(47 \%)$ & $747(45 \%)$ & $117(64 \%)$ & 0.000 & $\begin{array}{c}0.072 \\
1.614(0.958-2.717)\end{array}$ \\
\hline Splenectomy & $26(1 \%)$ & $25(2 \%)$ & $1(1 \%)$ & 0.507 & NA \\
\hline $\begin{array}{l}\text { Diagnosis } \\
\text { Adenocarcinoma } \\
\text { Lymphoma } \\
\text { GIST } \\
\text { Carcinoid } \\
\text { Others }\end{array}$ & $\begin{array}{c}1415(85 \%) \\
13(1 \%) \\
51(3 \%) \\
13(1 \%) \\
165(10 \%)\end{array}$ & $\begin{array}{c}1263(85 \%) \\
13(1 \%) \\
49(3 \%) \\
12(1 \%) \\
144(10 \%)\end{array}$ & $\begin{array}{c}152(86 \%) \\
0(0 \%) \\
2(1 \%) \\
1(1 \%) \\
21(12 \%)\end{array}$ & 0.301 & NA \\
\hline Operative time, mins & $241(152-333)$ & $235(144-328)$ & $291(220-353)$ & $<0.001$ & $\begin{array}{c}0.704 \\
1.000(0.998-1.003)\end{array}$ \\
\hline $\begin{array}{l}\text { Operative blood loss, } \\
\mathrm{mL}\end{array}$ & $75(50-200)$ & $75(50-200)$ & $100(50-200)$ & 0.065 & NA \\
\hline $\begin{array}{l}\text { Abnormal WBC on } \\
\text { POD3 (outside of } 4 \\
11 \mathrm{~K} / \mathrm{uL} \text { ) }\end{array}$ & $300(20 \%)$ & $257(20 \%)$ & $43(26 \%)$ & 0.049 & $\begin{array}{c}0.084 \\
1.596(0.939-2.713)\end{array}$ \\
\hline $\begin{array}{l}\text { Any phosphate } \\
\text { supplement POD\#0- } \\
3\end{array}$ & $429(24 \%)$ & $382(23 \%)$ & $47(26 \%)$ & 0.462 & NA \\
\hline $\begin{array}{l}\text { POD2 phosphate, } \\
\mathrm{mmol} / \mathrm{L} \text { Available }\end{array}$ & $\begin{array}{c}0.68(0.58-0.81) \\
1327(73 \%)\end{array}$ & $\begin{array}{l}0.68(0.58-0.81) \\
1181(72 \%)\end{array}$ & $\begin{array}{c}0.68(0.55-0.81) \\
146(80 \%)\end{array}$ & 0.601 & $\begin{array}{c}0.676 \\
1.275(0.409-3.973)\end{array}$ \\
\hline $\begin{array}{l}\text { POD3 phosphate, } \\
\mathrm{mmol} / \mathrm{L} \text { Available }\end{array}$ & $\begin{array}{c}0.77(0.65-0.90) \\
1303(71 \%)\end{array}$ & $\begin{array}{c}0.77(0.65-0.90) \\
1155(70 \%)\end{array}$ & $\begin{array}{c}0.74(0.65-0.90) \\
148(81 \%)\end{array}$ & 0.027 & $\begin{array}{c}0.518 \\
0.702(0.240-2.054)\end{array}$ \\
\hline $\begin{array}{l}\text { POD4 phosphate, } \\
\mathrm{mmol} / \mathrm{L} \text { Available }\end{array}$ & $\begin{array}{c}0.96(0.81-1.13) \\
1188(65 \%)\end{array}$ & $\begin{array}{c}0.96(0.81-1.13) \\
1051(64 \%)\end{array}$ & $\begin{array}{c}0.87(0.74-1.03) \\
137(75 \%)\end{array}$ & $<0.001$ & $\begin{array}{c}0.049 \\
0.355(0.127-0.996)\end{array}$ \\
\hline $\begin{array}{l}\text { POD5 phosphate, } \\
\text { mmol/L Available }\end{array}$ & $\begin{array}{c}1.10(0.94-1.23) \\
1089(60 \%)\end{array}$ & $\begin{array}{c}1.10(0.94-1.26) \\
949(58 \%)\end{array}$ & $\begin{array}{c}1.00(0.87-1.16) \\
140(77 \%)\end{array}$ & $<0.001$ & $\begin{array}{c}0.031 \\
0.330(0.121-0.902)\end{array}$ \\
\hline
\end{tabular}

Separate multivariate analysis of phosphate levels at each day below was performed with all significant factors from univariate analysis above.

Multivariate analysis with POD4 phosphate level is shown above, and the analyses with the other PODs are shown in the Supplementary Table 5.

Abbreviations: BMI, body mass index; CA, cancer; GIST, gastrointestinal stromal tumor; WBC, white blood cell count; NA, not analyzed.

Categorical variables are expressed as frequency $(\%)$. Phosphate levels and all other continuous variables are expressed as median $\left(1^{\text {st }}-3^{\text {rd }}\right.$ interquartile range). Number (\%) of patients with available phosphate level are as denoted (\#). 